\title{
Direct detection of Staphylococcus aureus in camel milk in the Nineveh governorate by using the PCR technique
}

\author{
O.H. Sheet ${ }^{1}$, Dh. M. Jwher ${ }^{1}$, R.A. Al-Sanjary ${ }^{1}{ }^{\circledR}$ and A.Dh. Alajami ${ }^{2}{ }^{\mathbb{D}}$ \\ ${ }^{1}$ Department of Veterinary Public Health, College of Veterinary Medicine, University of Mosul, Mosul, Iraq, ${ }^{2}$ Central \\ Veterinary Research Laboratories, Public Authority of Agriculture Affairs and Fish Resources, Kuwait
}

Article information

Article history:

Received June 22, 2020

Accepted September 15, 2020

Available online October 1, 2021

\section{Keywords:}

Staphylococcus aureus

nuc gene

Camel milk

PCR

\section{Correspondence:}

O.H. Sheet

omar.sheet@uomosul.edu.iq

\begin{abstract}
Staphylococcus (S.) aureus is the main facultative organism of contagious intramammary infections from lactating animals. It is considered a major foodborne organism that can cause food poisoning conditions around the world. Camels are very important to the lifestyle of many countries because they can produce milk that contains the major components such as proteins, energy, vitamins, and minerals. The present study used a polymerase chain reaction (PCR) method on a base of the nuc gene as a target gene, which is a specific gene that recognizes the $S$. aureus amongst other microorganisms. Fifty milk samples have been collected from camels from different areas of the Nineveh Governorate, Iraq. According to the phenotypic characteristics, isolation and identification of $S$. aureus have been accomplished by characterizing the shape of the colonies, painting the suspected isolates by gram stain, using the biochemical tests such as coagulase and catalase. In this study, S. aureus was isolated from 70\% (35/50) camel milk samples. The classical method of identifying the $S$. aureus isolated from camel milk was consistent with the PCR method. The PCR technique indicated that all positive S. aureus possessed the nис gene. The increased percentage of $S$. aureus isolated from the camel milk has a relationship with the type of farm management, poor nutrition, and/or environmental conditions, rather than treatment of the infected camel. The PCR method is considered one of the best-used techniques to identify the $S$. aureus isolated from camel milk by detection of $n u c$ gene, the specific gene of $S$. aureus.
\end{abstract}

DOI: 10.33899/ijvs.2020.127725.1524, (A)Athors, 2021, College of Veterinary Medicine, University of Mosul.

This is an open access article under the CC BY 4.0 license (http://creativecommons.org/licenses/by/4.0/).

\section{Introduction}

Staphylococcus. aureus is the major pathogenic bacteria isolated from various hosts, including humans, and different mammals as well as birds. S. aureus may be present as a commensal bacterium, which has the ability to colonization and growth in both human and veterinary medicine that lead to multiple infectious diseases outbreak (1). In addition, $S$. aureus has been able to cause mastitis in camels and other mammals. Furthermore, S. aureus is considered a foodborne pathogen that can cause food poisoning conditions around the world as a function of several types of virulence factors such as staphylococcal enterotoxins (SEs) and toxic shock syndrome toxin (TSST) (2). Dairy products are considered important vehicles that can transfer different types of pathogens such as $S$. aureus (3). Camels are able to live under the poor/harsh conditions in the desert. Camels are considered as a major vehicle transmission and a source of meat and milk for the humans in different areas around the world. Additionally, camels are the source of nutrition to humans by providing meat and milk, which has energy, proteins, vitamins, and minerals (4). In the past, camels were thought to be unaffected with any type of disease that infects animals. However, several studies showed that camel milk contained a high number of pathogens. Camels play an important role as a reservoir and the carrier of various infectious pathogens and zoonotic diseases that distribute them among the livestock (5). There 
are various methods, including the classical and modern methods, used to detect $S$. aureus (6). The classical methodology used for isolating and identifying pathogenic bacteria such as $S$. aureus includes microbiological media, then by biochemical tests and antimicrobial susceptibility examining. However, the classical methods may need from 48 to 72 hours to provide the final results (7). Many molecular identification methods have been utilized to recognize $S$. aureus isolated from mastitis milk. These methods are characterized as more accurate and rapid, and they identify the final decisions concerning the appropriate antimicrobial therapy (8). There are several molecular identification methods including polymerase chain reaction (PCR), real-time polymerase chain reaction (RT-PCR), and loop-mediated isothermal amplification (LAMP). PCR has been used in identification of different pathogens (9). In addition, PCR has been applied to reveal the speciesspecific gene acting as the pathogenic organism in clinical microbiology central laboratories (10). The specific gene of $S$. aureus is the nuc gene and the molecular methods for detecting this gene helped the scientists to rapidly identify S. aureus in clinical samples (11).

The objective of the current study was to isolate $S$. aureus from camel milk from different areas in the Nineveh Governorate. In addition, S. aureus isolates were detected based on the nuc gene by using oligonucleotides primer sets.

\section{Materials and methods}

\section{Camel milk samples}

A total of 50 milk samples were obtained from camels randomly collected from different areas around Nineveh Governorate between May and June 2019. The samples were collected directly from the udder as following: first streams were discarded, and the subsequent milk was placed in sterile tubes and stored in the cool box (12) and transported to the Department of Veterinary Public Health, College of Veterinary Medicine, Public Health Laboratory. All milk samples were inoculated on blood agar and Mannitol salt agar $7.5 \%$ plates $118 \mathrm{~g} / \mathrm{L}$. All the culture plates were aerobically incubated at $37^{\circ} \mathrm{C}$ for overnight.

\section{Identification of bacterial isolates}

Bacterial isolates were microscopically identified on a base of gram staining and cell morphology (13). Gram positive cocci and gram - negative bacteria were biochemically identified as previously described (14).

\section{DNA extraction and template preparation}

The suspected $S$. aureus isolates were streaked on sheep blood agar. Extraction of the DNA for $S$. aureus isolates was performed using DNeasy blood and tissue kit (Qiagen, Hilden, Germany). According to the instructions of the manufacturer, mature $S$. aureus colonies were lysed in 180

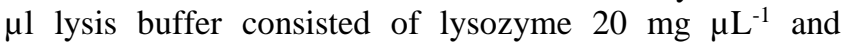

lysostaphin $3 \mu \mathrm{l} 1 \mathrm{mg} \mathrm{mL}-1$; for 30 minutes at $37^{\circ} \mathrm{C}$. Subsequently, $25 \mu \mathrm{L}$ proteinase $\mathrm{K} 20 \mathrm{mg} \mathrm{mL}^{-1}$ and $200 \mu \mathrm{L}$ AL buffer (Qiagen) were added to the mixture, bended by the vortexer, and incubated for 30 minutes at $56^{\circ} \mathrm{C}$. Later on, the suspension was placed in DNeasy Mini spin column, $200 \mu \mathrm{l}$ ethanol was added, and the mixture was centrifuged at $6200 \times \mathrm{g}$ for 1 minute. Next, the DNA in the spin column was rinsed two times: first by use of $500 \mu \mathrm{L}$ AW1 buffer with centrifugation at $6200 \times \mathrm{g}$ for 1 minute, and next by $500 \mu \mathrm{L}$ AW2 buffer with centrifugation at $17,000 \times \mathrm{g}$ for 3 minutes. The column spin was transfer to a $1.5 \mathrm{ml}$ microcentrifuge tube, where the DNA was harvested by adding $200 \mu \mathrm{L}$ AE buffer (Qiagen). Finally, DNA concentration was measured by use of micro-volume measurement platforms (Biodrop, United Kingdom) and stored at $-20^{\circ} \mathrm{C}$.

\section{PCR reaction}

The species-specific nuc gene was amplified by using the PCR assay to identify $S$. aureus. Extracted $S$. aureus DNA was amplified to detect the species-specific nuc gene with molecular weight of $166 \mathrm{bp}$ (15). The total volume of the mixture was $25 \mu \mathrm{L}$ and consisted of: $1 \mu \mathrm{L}$ forward primer 5-CCTGAAGCAAGTGCA TTTACGA-3 10 $\mathrm{pmol} / \mu \mathrm{L}$ (Eurofins Genomics, Ebersberg, Germany), $1 \mu \mathrm{L}$ of reverse primer 5-CTTTAGCCAAGCCTTGACGAACT$310 \mathrm{pmol} / \mu \mathrm{L}$ (Eurofins Genomics, Ebersberg, Germany), $12.5 \mu \mathrm{L}$ of $2 \times$ Go Taq Green Mix Master containing (1 unit GoldStar DNA polymerase, $400 \mu \mathrm{M}$ dNTPs, $3 \mu \mathrm{M} \mathrm{MgCl}_{2}$, $20 \mu \mathrm{M}(\mathrm{NH} 4)_{2} \mathrm{SO} 4,75 \mu \mathrm{M}$ TrisHCl (pH 8.5), yellow and blue dyes which function as loading dye (Promega Corporation, USA), $8 \mu \mathrm{L}$ of nuclease-free water (Promega Corporation, USA), and $2.5 \mu \mathrm{L}$ DNA template of S. aureus. The mixture was placed in PCR reaction tube (Biozym, Oldenhorf, Germany). The thermocycler program was set as the following: 5 minutes at $95^{\circ} \mathrm{C}$ for the denaturation, 35 cycles, where each cycle consisted of denaturation 30 seconds at $95^{\circ} \mathrm{C}$; annealing 30 seconds at $54^{\circ} \mathrm{C}$; and extension 30 seconds at $72^{\circ} \mathrm{C}$, and 5 minutes at $72^{\circ} \mathrm{C}$ for the final extension. Finally, the amplicons were determined by gel electrophoresis together with DNA marker 100 bp ladder in 2\% agarose gel (Peqlab, Erlangen, Germany).

\section{Results}

In this study, S. aureus was isolated from 35 (70\%) samples. All positive $S$. aureus isolates were round, goldenyellow colonies, when grown on mannitol salt agar. Furthermore, the isolates appeared hemolysis, when grown on blood agar plates. All positive isolates were, grampositive, catalase-positive, and coagulase-positive. The concentration of extracting DNA from the $S$. aureus isolates ranged from 75 to $125 \mathrm{ng} / \mu \mathrm{L}$. The PCR result indicated that the nuc gene was identified in $35(70 \%)$ of the isolates (Figure 1). The results of the microbiological method for identifying $S$. aureus isolates in camel milk has correlation of $100 \%$ with the result of the PCR assay. 


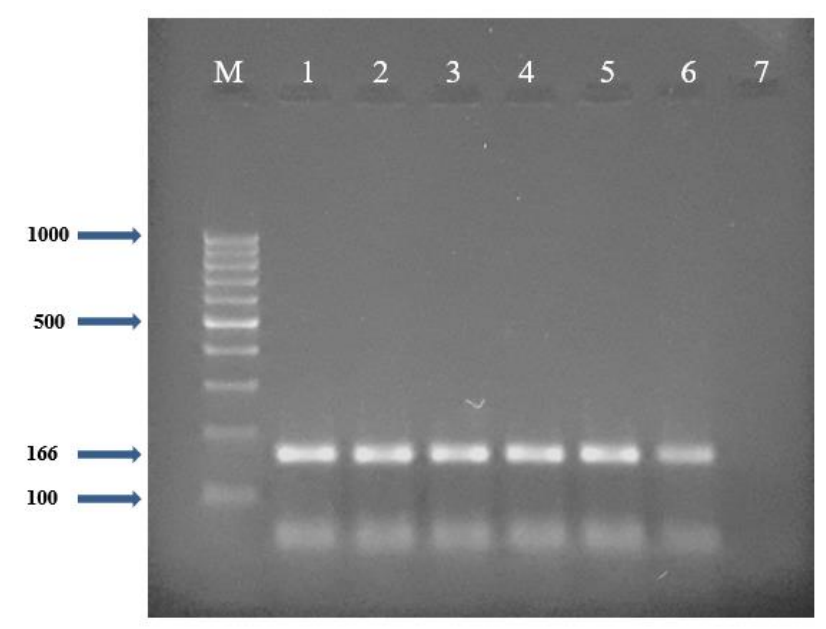

Figure 1: Identification of nuc gene (166 bp) in S. aureus using PCR technique.

\section{Discussion}

S. aureus is considered as a major cause of mastitis in camel and other mammary animals. In addition, it has the ability to produce several types of Staphylococcal Enterotoxins and thus is responsible for many food poisoning cases worldwide (16). Furthermore, S. aureus causes a huge economic loss which includes: inferior quality milk and decreased production, plus the therapeutic cost of treating the animals (17). There are many methods used to detect $S$. aureus, including classical methods that require about 24 hours to provide the final result. By comparison, the PCR technique is considered much faster and more accurate compared with the traditional methods. The PCR technique requires about 4 hours to identify the $S$. aureus isolates instead of 24 hours (18).

The present study revealed that $70 \%$ (35/50) of isolates were $S$. aureus. These results were in line with the result of a previous study which revealed that $75 \%(9 / 12)$ of $S$. aureus isolated from the camel milk was positive (19). The high incidence of mastitis could be attributable to the weak effect of the protective proteins (lysozyme, lactoferrin, lactoperoxidase, and immunoglobulin G, A) in camel milk on this bacterium $(20,21)$. In addition, the reason for the increased rate of $S$. aureus isolated from camel milk is the presence of $S$. aureus inside the udders or on the skin. $S$. aureus was also found in soil, bedding, water, manure, and calving pads (18). In addition, the milking utensils, the workers, and their clothes can have a function in spreading $S$. aureus between camels in the herd. Isolation of $S$. aureus from the milk is considered a public health concern (22).

The results of this study showed higher $S$. aureus percentages in comparison to previous studies: where $S$. aureus was isolated from camel milk at 61.2, and 38.9\% $(23,24)$. Utilizing good management practice with proper sanitation and monitoring udder health status, in coordination with the tick control measures, can lead to the elimination of existing infections in camels (25). Furthermore, the high percentage of S. aureus $70 \%$ in camel's milk may be due to camel farms' failure to adopt modern camel breeding programs. Good breeding management, better living conditions, culling suspected infected camels in the herd, and prompt treatment controls reduce spreading the pathogen among the herd and transferring it to other herds in the region. Additionally, the modern technique used for detecting the pathogens that will help to rapid diagnosis the disease and the decrease the spread of the disease among the camel herds.

\section{Conclusion}

The present study recommends that camel milk is tested frequently by using the classic or the modern assays to help prevent the spread of the pathogen within camel herds. More frequent testing can be achieved utilizing the PCR assay since it is more rapid and accurate than other methods.

\section{Acknowledgments}

The authors acknowledge efforts of the University of Mosul College of Veterinary Medicine and the Central Veterinary Research Laboratories personnel, and the Public Authority of Agriculture Affairs and Fish Resources, Kuwait, for providing all the facilities to carry out the project in their laboratories.

\section{Conflict of interest}

The author declares that there are no conflicts of interest regarding the publication of this manuscript.

\section{References}

1. Sheet $\mathrm{OH}$, Hussien SA, Alchalaby AY. Detection of methicillinresistant Staphylococcus aureus from broiler carcasses in Mosul city. $\begin{array}{llll}\text { Iraqi J Vet Sci. 2021;35(3):489-493. DOI: } & \end{array}$ 10.33899/ijvs.2020.127052.1451

2. Argudin MA, Mendoza MC, Rodicio MR. Food poisoning and Staphylococcus aureus enterotoxins. Toxins. 2010;2(7):1751-73. DOI: 10.3390/toxins2071751

3. De Buyser ML, Dufour B, Maire M, Lafarge V. Implication of milk and milk products in food-borne diseases in France and in different industrialized countries. Inter J Food Microbiol. 2001;67(1-2):1-17. DOI: $10.1016 / \mathrm{s} 0168-1605(01) 00443-3$

4. Soliman MM, Hassan MY, Mostafa SH, Ali HM, Saleh OM. Protective effects of camel milk against pathogenicity induced by Escherichia coli and Staphylococcus aureus in Wistar rats. Molecul Med Rep. 2012;12(6):8306-12. DOI: 10.3892/mmr.2015.4486

5. Graveland H, Duim B, van Duijkeren E, Heederik D, Wagenaar J A. Livestock-associated methicillin-resistant Staphylococcus aureus in animals and humans. Inter J Med Microbiol. 2011;301(8):630-4. DOI: 10.1016/j.ijmm.2011.09.004

6. Ercis S, Sancak B, Hascelik GA. Comparison of PCR detection of Meca with oxacillin disk susceptibility testing in different media and sceptor automated system for both Staphylococcus aureus and 
coagulase-negative Staphylococci isolates. Indian J Med Microbiol. 2008;26(1):21. DOI: 10.4103/0255-0857.38852

7. Stoakes L, Reyes R, Daniel J, Lennox G, John M A, Lannigan R. Prospective comparison of a new chromogenic medium, MRSASelect, to CHROMagar MRSA and mannitol-salt medium supplemented with oxacillin or cefoxitin for detection of methicillin-resistant Staphylococcus aureus. J Clin Microbiol. 2006;44(2):637-9. DOI: 10.1128/jcm.44.2.637-639.2006

8. Jonas D, Speck M, Daschner F D, Grundmann H. Rapid PCR-based identification of methicillin-resistant Staphylococcus aureus from screening swabs. J Clin Microbiol. 2002;40(5):1821-3.DOI: 10.1128/jcm.40.5.1821-1823.2002

9. Huletsky A, Giroux R, Rossbach V, Gagnon M, Vaillancourt M, Bernier M. new real-time PCR assay for rapid detection of methicillin- resistant Staphylococcus aureus directly from specimens containing a mixture of Staphylococci. J Clin Microbiol. 2004;42(5):1875-84. DOI: $10.1128 / \mathrm{jcm} .42 .5 .1875-1884.2004$

10. Taponen S, Pyorala S. Coagulase-negative Staphylococci as cause of bovine mastitis-Not so different from Staphylococcus aureus? Vet Microbiol. 2009;134(1-2):29-36. DOI: 10.1016/j.vetmic.2008.09.011

11. Hishiyar A H, Mahde SA. Molecular fingerprinting of methicillin resistant Staphylococcus aureus strains isolated from human and poultry in Duhok, Iraq. Iraqi J Vet Sci. 2021;35(1):99-103. DOI: 10.33899/ijvs.2020.126375.1310

12. Haider H, A-Fatlawy MA. Morphological and molecular identification of Parabronema skrjabini of camels (Camelus dromedary) in Najaf province. Iraqi J Vet Sci. 2021;35(3):507-512. DOI: 10.33899/ijvs.2020.127101.1459

13. Cruickshank R, Duguid BP, Mien M, Swain RA. Medical microbiology. 12 $2^{\text {th }}$ ed. Edinburgh: Churchill Living Stone; 1975. [available at]

14. Quinn PJ, Markey BK, Carter ME, Donnelly WC, Leonard FC, Maguire D. Veterinary microbiology and microbial diseases. $1^{\text {st }}$ ed. UK: Blackwell Science Ltd; 2002: 14-197 p. [available at]

15. Graber HU, Casey MG, Naskova J, Steiner A, Schaeren W. Development of a highly sensitive and specific assay to detect Staphylococcus aureus in bovine mastitic milk. J Dairy Sci. 2007;90(10):4661-9. DOI: 10.3168/jds.2006-902

16. Hennekinne JA, Ostyn A, Guillier F, Herbin S, Prufer AL, Dragacci S. How should Staphylococcal food poisoning outbreaks be characterized? Toxins. 2010;2(8):2106-16. DOI: 10.3390/toxins 2082106

17. Keefe G. update on control of Staphylococcus aureus and Streptococcus agalactiae for management of mastitis. veterinary clinics of north America. Food Anim Practice. 2012;28(2):203-16. DOI: $10.1016 /$ j.cvfa.2012.03.010

18. Izadpanah M, Mohebali N, Elyasi Z, Farzaneh P, Vakhshiteh F, Shahzadeh A. Simple and fast multiplex PCR method for detection of species origin in meat products. J Food Sci Technol. 2017;55(2):698703. DOI: $10.1007 / \mathrm{s} 13197-017-2980-2$

19. Hawari $\mathrm{AD}$, Hassawi DS. Mastitis in One humped she-camels (Camelus dromedarius) in Jordan. J Biol Sci. 2008;8(5):958-61.DOI: 10.3923/jbs.2008.958.961

20. Barbour EK, Nabbut NH, Frerichs WM, Al-Nakhli HM. Inhibition of pathogenic bacteria by camel's milk: Relation to whey lysozyme and stage of lactation. J Food Protect. 1984;47(11):838-40. DOI: 10.4315/0362-028x-47.11.838

21. El Agamy EI, Ruppanner R, Ismail A, Champagne CP, Assaf R. Antibacterial and antiviral activity of camel milk protective proteins. J Dairy Res. 1992;59(2):169-75. DOI: 10.1017/s0022029900030417

22. El-Ziney MG. Microbiological quality and safety assessment of camel milk (Camelus Dromedaries) in Saudi Arabia (Qassim region). Appl Ecol Environ Res. 2007;5(2):115-22.DOI: 10.15666/aeer/0502_115122

23. Abdurahman OS. The detection of subclinical mastitis in the bactrian camel (Camelus bactrianus) by somatic cell count and California mastitis test. Vet Res Comm. 1996;20(1):9-14. DOI: $10.1007 / \mathrm{bf00346570}$

24. Pratap SC, Mathur M, Dadhich H, Ganguly S. Molecular characterization of Staphylococcus aureus of camel (Camelus dromedarius) skin origin. Inter $\mathrm{J}$ Curr Microbiol Appl Sci. 2018;7(1):3486-90. DOI: 10.20546/ijcmas.2018.701.410

25. Seifu E, Tafesse B. Prevalence and etiology of mastitis in traditionally managed camels (Camelus dromedarius) in selected pastoral areas in eastern Ethiopia. Ethiop Vet J. 2010;14(2):103-113. DOI: $\underline{10.4314 / \text { evj.v14i2.63887 }}$
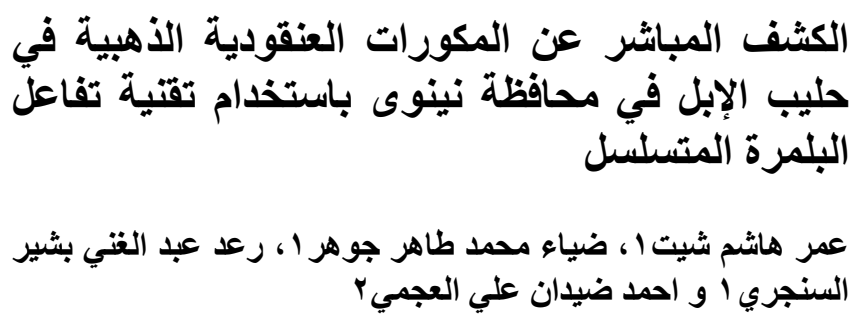

ا فرع الصحة العامة البيطرية، كلية الطب البيطري، جامعة الموصل،

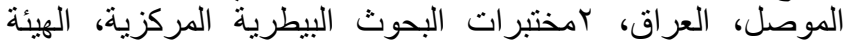

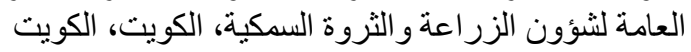

الخلاصة

تعد جر اثيم المكورات العنقودية الذهبية المسبب الرئيسي للإصسابة

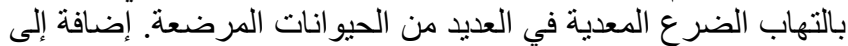

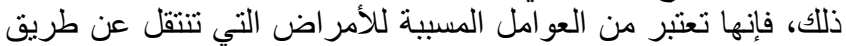
الأغذية وكذلك فإنها مسؤولة عن حالات التهات التسمم الغذائي في جميع أنحاء

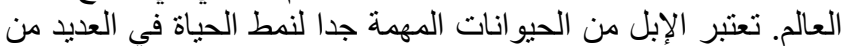

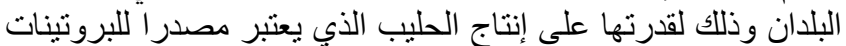
و الطاقة والفيتامينات و المعادن. في هذه الدراسة الثات، تعتمد تقنية تفاعل البلمرة المتسلسل على الجين nuc، وهو جين خاص يستعمل لتمبيز و التعرف على المكورات العنقودية الذهبية عن بقية الكائنات الحية

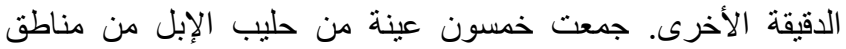

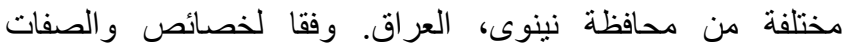
المظهرية، تم عزل المكورات العنقودية وتحديدها عن طريق المظهري

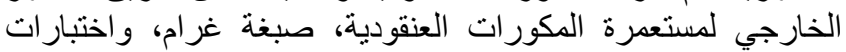

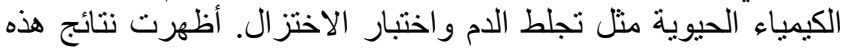

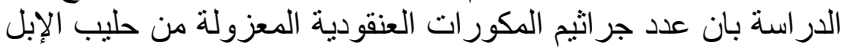

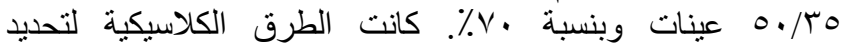
المكورات العنقودية الذهبية المعزولة من حليب الإبل منو افقة مع طريقة

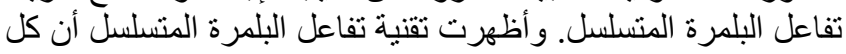

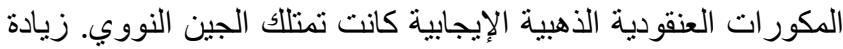

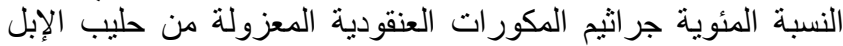

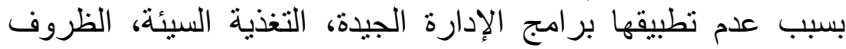

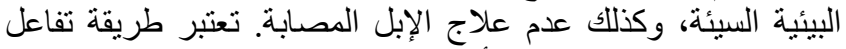

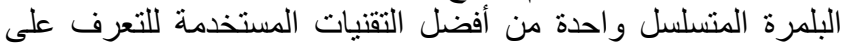

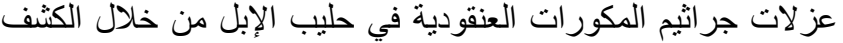

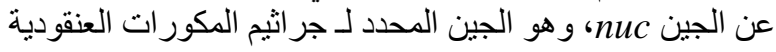

